\title{
Güvercin (Columbia domestica) Dışkılarında Chlamydia psittaci ompA Geninin Araştırılması ve Genotiplendirilmesi
}

\section{Investigation and Genotyping of Chlamydia psittaci ompA Gene in Pigeon (Columbia domestica) Feces}

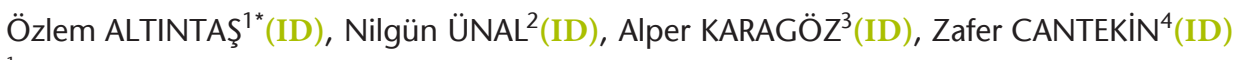 \\ 1 T.C. Tarım ve Orman Bakanlığı, Veteriner Kontrol Merkez Araştırma Enstitüsü, Bäkteri Teșhis Laboratuvarı, Ankara. \\ ${ }^{1}$ Republic of Turkey Ministry of Agriculture and Forestry, Veterinary Control Central Research Institute, Bacteria Diagnosis \\ Laboratory, Ankara, Turkey. \\ 2 Sağlık Bilimleri Üniversitesi Gülhane Eczacılık Fakültesi, Farmasötik Mikrobiyoloji Anabilim Dalı, Ankara. \\ 2 University of Health Sciences Gulhane Faculty of Pharmacy, Department of Pharmaceutical Microbiology, Ankara, Turkey. \\ ${ }^{3}$ Uşak Üniversitesi Fen-Edebiyat Fakültesi, Moleküler Biyoloji ve Genetik Bölümü, Mikrobiyoloji Anabilim Dalı, Uşak. \\ ${ }^{3}$ Usak University Faculty of Arts and Sciences, Department of Molecular Biology and Genetics, Department of Microbiology, \\ Usak, Turkey. \\ ${ }^{4}$ Hatay Mustafa Kemal Üniversitesi Veteriner Fakültesi, Mikrobiyoloji Anabilim Dalı, Hatay. \\ ${ }^{4}$ Hatay Mustafa Kemal University Faculty of Veterinary, Department of Veterinary Microbiology, Hatay, Turkey.
} * Bu çalışma, ilk yazarın Kırıkkale Üniversitesi Sağlık Bilimleri Enstitüsü tarafından onaylanan doktora tezi çalışmasını içer-
mektedir.

Makale Atıfı: Altıntaş Ö, Ünal N, Karagöz A, Cantekin Z. Güvercin (Columbia domestica) dışkılarında Chlamydia psittaci ompA geninin araştırılması ve genotiplendirilmesi. Mikrobiyol Bul 2020;54(1):144-153.

\section{ÖZ}

Kanatı klamidiyozisi evcil ve yabani kanatlılarda görülebilen, oldukça bulaşıcı ve sistemik bir hastalıktır. Hastalık etkeni Chlamydia psittaci, Chlamydiaceae familyasında, gram-negatif ve sadece hücre içerisinde yaşayabilen bir bakteridir. Etken insanlara, enfekte hayvanla temas ve dışkı aracılığıyla bulaşabileceği gibi etkeni içeren dışkı tozlarının solunmasıyla da bulaşabilir. Hastalık zoonoz bir karakter taşıdığı için halk sağlığı yönüyle de önemlidir. C.psittaci etkeninin hücre duvarı proteinlerine (OMP) karşı monoklonal antikorların kullanımıyla kanatlılarda altı (A-F), memelilerde iki (WC ve M56) serotip belirlenmiştir. Serotiplerde konak özgüllüğü vardır. Moleküler genotiplendirmede hücre duvarı proteinlerini kodlayan "major outer membrane protein/MOMP" ompA geni kullanılmaktadır. Bu çalışmada, Ankara'da on farklı ilçede bulunan aile işletmeciliği tarzında yetiştirilen, evcil güvercin dışkılarında C.psittaci ompA geni varlığının kış ve yaz mevsimlerinde araştırılması ve ompA geninin dizi analizi ile genotiplendirilmesi amaçlanmıştır. Çalışma kapsamında Ankara ilinde 10 farklı ilçede (Beypazarı, Haymana, Kızılcahamam, Çubuk, Pursaklar, Bala, Çankaya, Polatlı, Gölbaşı ve Merkez) bulunan kuşhanelerden iki farklı mevsimde 100 güvercin dışkı örneği toplanmıştır. Toplanan dışkı örneklerinden DNA eldesi klasik yöntemlerle yapılmıştır. Dışkıdan elde edilen DNA örneklerinde etkenin varlığı ompA geninin polimeraz zincir reaksiyonu (PCR) analizi ile araştırılmıştır. PCR ile çoğaltılan hedef DNA ürünlerinden çalışmada kullanılan primerler ile ompA geninin çift yönlü dizi analizi yapılmıştır. Dizi analizi sonuçları uluslararası veri tabanı ile karşılaştırılarak serotiplendirme/ 
genotiplendirme yapılmıştır. Çalışmada 100 güvercin dışkı örneğinden altı örnekte C.psittaci ompA geni tespit edilmiştir. Bu pozitif örneklerin ikisi Bala (bir kış ve bir yaz dönemi numunesi), ikisi Haymana (bir kış, bir yaz dönemi numunesi), ikisi Gölbaşı (bir kış, bir yaz dönemi numunesi) ilçelerinden olmak üzere aynı kuşhanelerden farklı mevsimlerde izole edilmiştir. Bu çalışma ile güvercin dışkılarında C.psittaci'nin varlığı ile mevsim arasında bir fark belirlenmemiştir. Ayrıca, bu çalışmada pozitif örneklerde ompA geni dizi analiz sonuçlarının Dünya veri bankası ile karşılaştırıldığında bütün izolatların \%100 oranında genotip B, \%99 oranında da genotip E ile uyumlu olduğu görülmüştür. Türkiye'de, ompA geninin dizi analizi ile evcil güvercin kökenli C.psittaci genotipi ilk kez bu çalışmada belirlenmiştir. C.psittaci'nin zoonoz bir bakteri olması ve evcil güvercinlerde düşük oranda da olsa bulunması halk sağlığı açısından önemlidir.

Anahtar kelimeler: Chlamydia psittaci; dışkı; avian; ompA; polimeraz zincir reaksiyonu.

\section{ABSTRACT}

Avian chlamydiosis, is a highly contagious, systemic disease occuring in domestic and wild birds. Chlamydia psittaci, the causative agent of the disease, is a gram-negative bacterium in the Chlamydiaceae family that can only live within the cell. The agent can be transmitted directly to humans by contact with infected animals or feces of infected animals. It can also be transmitted by inhalation of fecal dust. Since the disease has a zoonotic character, it is also important in terms of public health. By using the monoclonal antibodies against cell wall proteins (OMP) of C.psittaci, six (A-F) and two (WC and M56) serotypes were determined in mammals. The aim of this study was to investigate and genotype the presence of C.psittaci ompA gene in domestic pigeon feces grown in family management style in ten different districts in Ankara in winter and summer seasons. Within the scope of the study, 100 pigeon stool samples were collected from birdhouses in 10 different districts of Ankara (Beypazari, Haymana, Kizilcahamam, Cubuk, Pursaklar, Bala, Cankaya, Polatli, Golbasi and city center) in two different seasons. DNA extraction from fecal samples was performed by classical methods. The presence of the agent in the extracted DNA samples was investigated by polymerase chain reaction (PCR) analysis of the ompA gene. Two-way sequence analysis of the ompA gene was performed with the primers used in the study from the target DNA products amplified by PCR. The results of sequence analysis were compared with the international database and serotyping/genotyping was performed. In the study, C.psittaci ompA gene was detected in $6(6 \%)$ samples of 100 pigeon stool samples. Among these positive samples, two were from Bala (one sample from winter, one sample from summer), two were from Haymana (one sample from winter, one sample from summer) and two were from Golbasi (one sample from winter, one sample from summer); where the same agent was isolated in the same aviaries in different seasons. In this study, no difference was found between the presence of C.psittaci in pigeon droppings and season. In addition when the sequence analysis of the isolated samples were compared with the World database; all isolates were found to be $100 \%$ genotype B and $99 \%$ genotype $E$. In this study, the sequence analysis of the ompA gene of C.psittaci from domestic pigeon feces was determined for the first time in Turkey. Although the presence of C.psittaci in domestic pigeons is low, it is a zoonotic bacterium and is important for the public health.

Keywords: Chlamydia psittaci; feces; ompA; polymerase chain reaction; pigeon.

\section{Gíriş}

Kanatlı klamidiyozisi hem evcil hem de yabani kanatlılarda görülebilen, bulaşıcı, sistemik ve zoonotik bir hastalıktır. Hastalık etkeni Chlamydia psittaci'dir. Etken zoonotik bir karakter taşıdığı için, halk sağlığı yönüyle de önem taşımaktadır. Klamidya etkenlerine bağı olarak memelilerde ve kuşlarda gelişen hastalıkların isimlendirilmesi zaman içerisinde değişikliklere uğramıştır. "Parrot hastalığı", "Parrot ateş", "Psittacosis", "Chlamydiosis", "Chlamydophilosis" ve "Ornithosis" bu isimlendirmelerden bazılarıdır. Bu tanımlar içerisinde yer alan psittakoz psitasin kuşlar (papağan, muhabbet kuşu) ile 
insanlarda görülebilen hastalığı tanımlarken; ornitoz ise psitasin sınıfında yer almayan (serçe, güvercin, evcil kanatlılar vb.) kuşlarda görülen hastalığı tanımlamaktadır. Günümüzde genellikle kanatlı klamidyası kanatlılarda görülen hastalığı tanımlamada kullanılırken; psittakoz insanlarda, psitasin de kuşlarda görülen hastalığı tanımlamak için tercih edilmektedir ${ }^{1-5}$.

Etken, insanlara ya doğrudan temasla ya da dışkı tozlarının solunmasıyla; enfekte hayvanların salgıları aracılığıyla bulaşabilir. Özellikle kafes kuşu yetiştiriciliği yapanlar ve evde kuş besleyenlerde, etkenle bulaşık dışkı tozlarının solunması sonucu enfeksiyon bulaşabilmektedir. Bu nedenle bu tür durumlarda maske kullanılması gereklidir ${ }^{2}$.

Günümüze kadar klamidya etkenleri için değişik isimlendirmeler kullanılmıştır. İsimlendirmede yapılan bu değişikliklerin nedeni; etkenin çoğalma aşamasındaki farklılıkları, mikrobiyal yapısı ve etkenin izolasyonu ile tanımlanmasında kullanılan yöntemlerdeki gelişmelerdir ${ }^{6}$. Etken son olarak Chlamydia psittaci olarak isimlendirilmiştir ${ }^{7}$.

C.psittaci etkeninin hücre duvarı dış zarında bulunan proteinlere karşı monoklonal antikorların kullanımı ile kanatlılarda altı (A-F), memelilerde iki (WC ve M56) serotipi belirlenmiştir. Ayrıca, kesin olmayan 1V, YP84, R54, 6N, CPX0308, I gibi alt genotipleri de vardır. Serotiplerde konak özgüllüğü vardır ${ }^{8}$. Serotip A esas olarak psitasin kuşlarından, serotip B esas olarak güvercinlerden, serotip C çoğunlukla ördeklerden ve kazlardan, serotip D çoğunlukla hindilerden, serotip $E$ ise çoğunlukla güvercinlerden ve diğer kuşlardan izole edilir. $\mathrm{F}$ ise temel olarak muhabbet kuşlarından ve hindilerden izole edilir. Moleküler genotiplendirmede hücre duvarı dış zar proteinlerini (major outer membrane protein/MOMP) kodlayan ompA geni dizi analizi ile genotipler E/B dahil ek genotiplerde kullanılmaktadır? .

Bu çalışmada, Ankara ili ve ilçelerinde aile yetiştiriciliği tarzında beslenen evcil güvercinlerin barındırıldığı kuşhanelerde C.psittaci ompA geni varlığının iki farklı mevsimde polimeraz zincir reaksiyonu (PCR) ile araştırılması ve ompA geninin dizi analizi ile genotiplerinin belirlenmesi amaçlanmıştır.

\section{GEREÇ ve YÖNTEM}

Bu çalışma, Kırıkkale Üniversitesi Klinik Araştırmalar Etik Kurulu onayı ile gerçekleştirildi (Tarih: 02.12.2016 ve Karar no: 001.00.00.23).

\section{Örneklerin Toplanması}

Psittakoz, güvercinlerde klinik ve subklinik olarak seyredebilmektedir. Enfeksiyonu iyileşen güvercinler taşıyıcı olarak bulunmakta ve etkeni dışkı ile bulaştırabilmektedir. C.psittaci etkeni zoonozdur. Bu etkenin insanlara bulaşmasında en önemli yol enfekte hayvanların burun akıntıları aracılığıyla veya etkenle bulaşık dışkılarladır ${ }^{10,11}$. Bu nedenle çalışmada dışkı örnekleri seçildi. Etkenin zorunlu hücre içi bir bakteri olması, hücre kültürü gibi zor ve pahalı laboratuvar olanakları gerekmesi nedeniyle, araştırmada PCR 


\begin{tabular}{lccc}
\multicolumn{2}{l}{ Tablo I. Çalışılan Örneklere Göre Pozitif ve Negatiflerin Dağıımı } & \\
\cline { 2 - 3 } ilı̧e & \multicolumn{2}{c}{ Alınan örnek sayısı } & \\
\cline { 2 - 3 } Beypazarı & Pozitif/Kış & Pozitif/Yaz & Pozitif/Toplam \\
Haymana & $0 / 5$ & $0 / 5$ & $0 / 10$ \\
Kızılcahamam & $1 / 5$ & $1 / 5$ & $2 / 10$ \\
Çubuk & $0 / 5$ & $0 / 5$ & $0 / 10$ \\
Pursaklar & $0 / 5$ & $0 / 5$ & $0 / 10$ \\
Bala & $0 / 5$ & $0 / 5$ & $0 / 10$ \\
Çankaya & $1 / 5$ & $1 / 5$ & $2 / 10$ \\
Polatlı & $0 / 5$ & $0 / 5$ & $0 / 10$ \\
Gölbaşı & $0 / 5$ & $0 / 5$ & $0 / 10$ \\
Merkez & $1 / 5$ & $1 / 5$ & $2 / 10$ \\
Toplam & $0 / 5$ & $0 / 5$ & $0 / 10$ \\
\hline
\end{tabular}

yöntemi kullanıldı. Ankara ve ilçelerinde (Tablo I) güvercin yetiştiren 50 kuşhaneden, kış ve yaz dönemi olmak üzere iki farklı zamanda (aynı çiftlikler ziyaret edilerek), her kuşhaneden 10 gram dışkı örneği olacak şekilde toplamda 100 adet örnek steril tüplere alındı. Örnekler alınırken, güvercinlerde klinik herhangi bir belirti gözlemlenmedi. Örnekler alınırken kuşhanenin beş farklı bölgesinden numune alınmasına özen gösterildi. Toplanan örnekler soğuk zincir şartları altında en kısa sürede laboratuvara ulaştıııldı. PCR çalışması yapılana kadar tüm örnekler $-20^{\circ} \mathrm{C}^{\prime}$ de muhafaza edildi.

\section{Dışkı Örneklerinden DNA İzolasyonu ve Polimeraz Zincir Reaksiyonu}

Toplanan örnekler $-20^{\circ} \mathrm{C}^{\prime}$ de derin dondurucudan çıkartılıp oda ısısında çözdürüldü. Steril tüpler içerisindeki 10 gram ağırlığındaki örnekler $50 \mathrm{ml}$ steril fizyolojik tuzlu su (FTS) ile iyice karıştııılı ve dışkının sıvı içerisinde çözünmesi sağlandı. Bu işlemi takiben 30 dakika beklenip, kaba partiküllerin tüpün dibinde çökmesinin ardından üstteki sıvıdan $5 \mathrm{ml}$ alınarak steril tüpler içerisine aktarılarak 5000 devirde 10 dakika süre ile santrifüj edildi. Üstteki sıvı atıldıktan sonra, dipteki tortudan DNA izolasyonu Sambrook ve Russell ${ }^{12 \prime \prime n}$ bildirdiği yönteme göre yapıldı ve bu DNA süspansiyonları kalıp olarak kullanılarak PCR amplifikasyon işlemleri yapıldı. Bu yönteme göre cam santrifüj tüplerindeki tortuda PCR inhibitörü olabilecek enzimlerin uzaklaştırılması amacıyla $1 \mathrm{ml}$ metil alkol içerisinde karıştırıldı ve bu karışım steril plastik mikrosantrifüj tüplerine aktarıldı.

Hazırlanan karışımlar 3500 rpm'de 10 dakika süreyle santrifüj edildikten sonra üst sıvı atıldı ve dipteki yıkanmış tortu tekrar $1 \mathrm{ml}$ steril PBS ile karışııııldı ve aynı santrifüj işlemi uygulandı. Bu adımın arkasından dipte oluşan kalıntı $1 \mathrm{ml}$ TES solüusyonu eklenerek elde edilen karışım tekrar santrifüj edildi. Üst sıvı atıldıktan sonra dipteki tortu lizozim (12.5 
$\mu \mathrm{g} / \mathrm{ml}$ ) içeren $500 \mu \mathrm{l}$ TES tamponu ile süspanse haline getirilerek $37^{\circ} \mathrm{C}^{\prime}$ de 60 dakika inkübe edildi. Bu sürenin sonunda $20 \mu \mathrm{l} \% 10^{\prime}$ luk sodyum dodesil sülfat (SDS) ve $10 \mu \mathrm{l}$ proteinaz $\mathrm{K}(10 \mu \mathrm{g} / \mu \mathrm{l})$ eklenerek vortekslendikten sonra $65^{\circ} \mathrm{C}^{\prime}$ de 30 dakika inkübe edildi.

Tüm inkübasyonlar sırasında enzimlerin etkinliğinin artırılması amacıyla 15 dakika aralarla tüpler hafifçe vortekslendi. İnkübasyon işlemlerinin bitmesinden sonra protein ve diğer hücre artıklarının bağlanması için karışım üzerine, eşit miktarda fenol: kloroform: izoamil alkol (25:24:1) ilave edilip, vortekslendikten sonra 10.000 rpm'de 10 dakika süreyle santrifüj edildi. Üst tabaka dikkatlice yeni bir tüpe alınarak üzerine 0.1 hacim 3 $\mathrm{M}$ sodyum asetat ve 1-2 hacim absolü etanol ilave edilerek $-20^{\circ} \mathrm{C}^{\prime}$ de bir gece bekletildi.

Ertesi gün karışım 13.000 rpm'de 10 dakika süreyle santrifüj edildikten sonra üstteki sıvı atıldı ve dipteki çökelti önce $\% 96^{\prime}$ lık, sonra \%70'lik etanol ile yıkamayı takiben kurutulup, $100 \mathrm{ml}$ DEPC su ile süspanse edildi. Bu süspansiyon PCR analizlerinde kullanılmak üzere $-20^{\circ} \mathrm{C}^{\prime}$ de saklandı. PCR amplifikasyonu amacıyla karışım hazırlanırken, ekstrakte edilerek hazırlanmış olan bu sıvıdan $5 \mu$ l alınarak PCR'de kalıp DNA olarak kullanıldı ${ }^{12}$.

Çalışmamızda C.psittaci etkeninin PCR ile belirlenmesi işlemi Laroucau ve arkadaşla$\mathrm{rı}^{13}$ tarafından önerilen protokole göre; omp gen bölgesi dış membran faktörü (OMF) hedef alan Cpsi A ileri (5'-ATG AAA CAT CCA GTC TAC TGG -3') ve Cpsi B ters (5'-TTG TGT AGT AAT ATT ATC AAA-3’) primerleri kullanılarak çoğaltıldı. PCR ve DNA dizi analizi yöntemlerinde kontrol suş olarak C.psittaci ATCC VR-125 (AY581777.1) kullanıldı.

Amplifikasyon sonrasında oluşan ürünlerin değerlendirilmesi için \%1.5'lik agaroz jel hazırlanarak kullanıldı. Agaroz jel hazırlanırken tampon çözelti olarak 1x TBE tamponu kullanıldı ve soğumakta olan agaroz jel çözeltisine $10 \mu \mathrm{l}$ etidyum bromür eklenerek, yatay jel elektroforez tablasına dökülüp soğumaya bırakıldı. Katılaşan jel, elektroforez işleminde kullanıldı ${ }^{12}$.

Elde edilen amplifikasyon ürünlerinden $10 \mu$ lalınarak, $2 \mu$ l 6X yükleme tamponu ile karıştırıldı ve bu karışımın hepsi jele yüklenerek amplifikasyon ürünleri $120 \mathrm{~V} 60$ dakika süreyle elektroforeze tutuldu ${ }^{12}$. Jeldeki örnekler bilgisayarlı UV transiluminatör kutusu içine yerleştirilerek görüntülendi ve fotoğrafları çekildi ${ }^{12}$.

\section{Dizi Analizi}

PCR sonucu elde edilen amplifikasyon ürünü (ompA geni) jelden ekstrakte edildikten sonra, elde edilen DNA'dan çalışmada kullanılan primerler ile iki yönlü dizi analizi yapıldı. DNA dizi analizi işlemi için; üretici firma önerisi ile ABI Prism 3700 Genetic Analyzer (Thermo Fisher Scientific, Massachusetts, ABD) cihazı ile BigDye Terminator V3.1 Cycle Sequencing Kit (Applied Biosystems, Kaliforniya, ABD) kullanıldı. Filogenetik analiz amacıyla gen bankası üzerinden temin edilen dizilerle Mega 4.0 programı (neighbor-joining method) kullanıldı ${ }^{14}$. 


\section{BULGULAR}

Çalışmada Ankara ve çevresinde güvercin yetiştirilen kuşhanelerden toplanan 100 adet dışkı örneğinde DNA izolasyonu gerçekleştirilmiş olup; 100 örnekten altı örnekte C.psittaci ompA geni pozitif olarak bulunmuştur.

Pozitif olarak bulunan örneklerin ikisi Bala (biri Aralık-Mart/kış, biri Haziran-Ağustos/yaz dönemi numunesi), ikisi Haymana (biri Aralık-Mart/kış, biri Haziran-Ağustos/yaz dönemi numunesi), ikisi Gölbaşı (biri Aralık-Mart/kış, biri Haziran-Ağustos/yaz dönemi numunesi) ilçelerinden olmak üzere aynı kuşhanelerden farklı mevsimlerde izole edilmiştir (Tablo I).

Elde edilen veriler kullanılarak yapılan ki-kare testine göre mevsim açısından iki grup arasındaki fark önemsiz bulunmuştur.

Jel elektroforez yöntemi kullanılarak görüntülenen PCR amplifikasyon ürünleri Resim 1 'de görülmektedir.

Pozitif olarak bulunan numuneler arasında yer alan örneğe ait DNA dizi analiz sonucu Şekil 1'de verilmiştir.

Altı adet örnek birbirleriyle \%100 uyum göstermiştir (Homoloji: \%100). Altı adet örnek kontrol suşu (AY581777.1) ile birlikte karşılaştırıldığında, kontrol suşu ile \%99.7 uyum göstermiştir (Homoloji: \%99.7) (Şekil 2). Dünya veri bankasında yer alan dizi analizleri karşılaştırıldığında bütün izolatlar \%100 genotip B ile \%99 oranında da genotip E ile uyum göstermiştir.

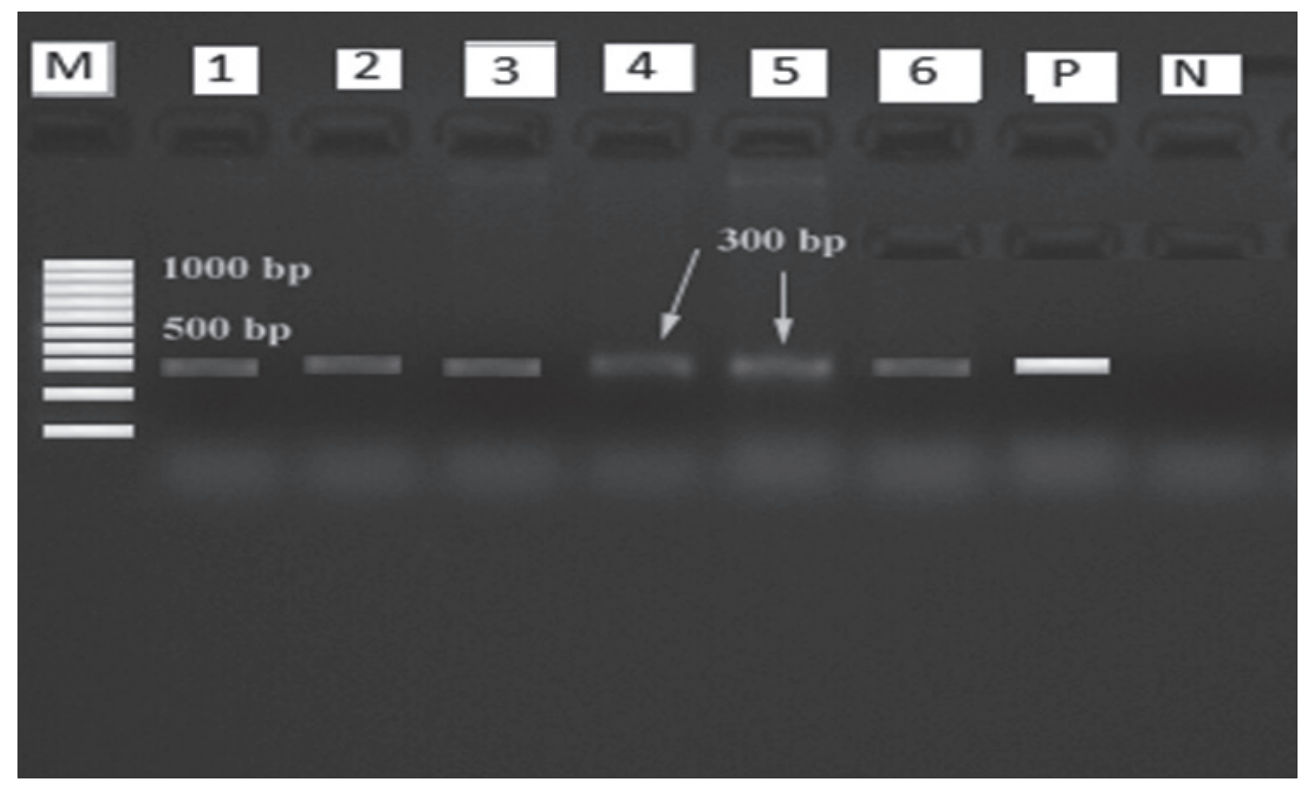

Resim 1. PCR amplifikasyon ürünleri. M: 100 bp'lik moleküler ağırlık belirteci, 1-6 arası pozitif örnekler, N: Negatif. 


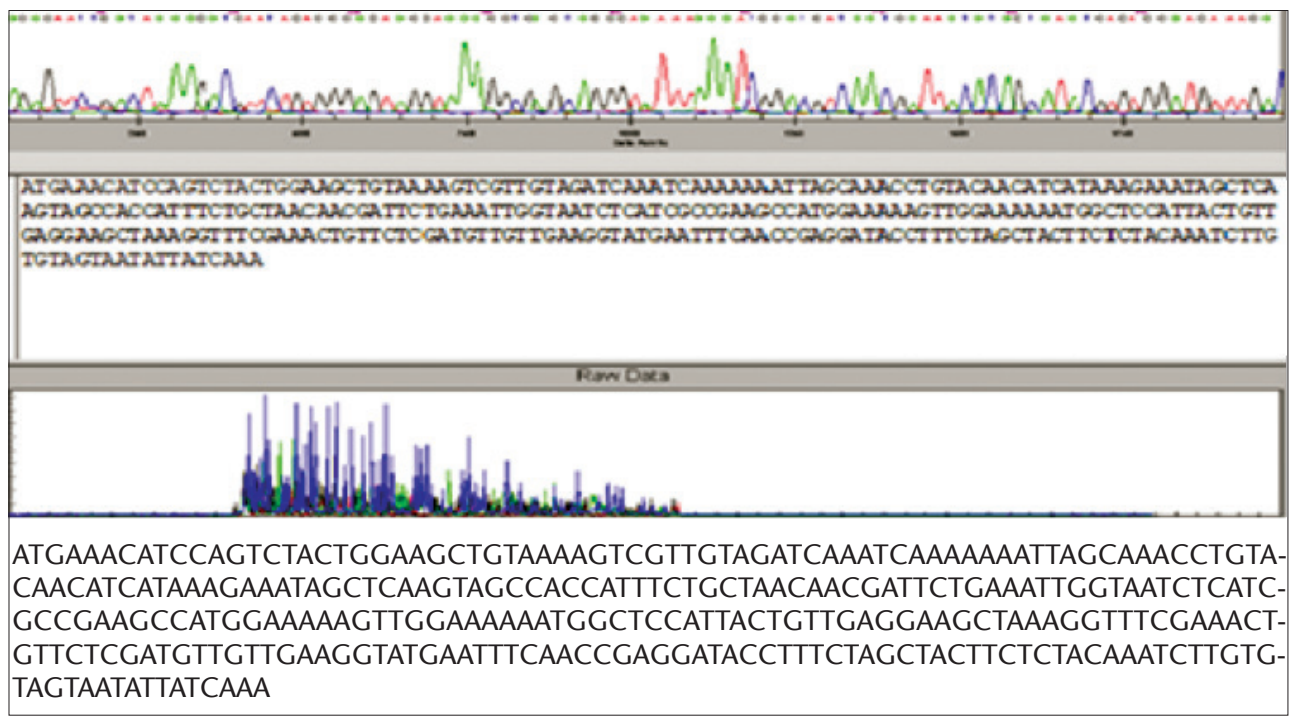

Şekil 1. Pozitif örneğe ait dizi analiz piki.

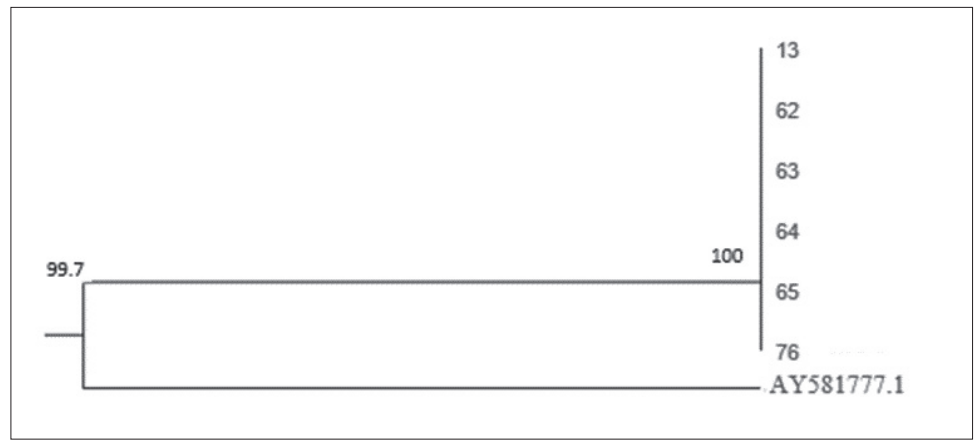

Şekil 2. DNA dizi analiz sonucu yapılan dendogram (filogenetik analiz).

\section{TARTIŞMA}

Son yıllarda yapılan çalışmalarda farklı kanatlı hayvan türlerinde C.psittaci varlığı \%1.883.0 oranlarında bildirilmiştir ${ }^{1,8,11,15}$. Ingiltere'de farklı türlerde yabani kuşlardan alınıp depolanmış 40 doku örneğinin $21^{\prime}$ inde C.psittaci pozitif olarak belirlenmiştir ${ }^{16}$. Güvercinlerde dışkı örneklerinden PCR yöntemi ile yapılan çalışmalarda bildirilen etken prevalansı ise \%3.4 ile \%50 arasındadır $^{17}$. Almanya'da şehirlerde yaşayan yabani güvercinlerden kloakal sürüntü ve dışkı örnekleri toplanarak PCR ile analiz edildiğinde, kloakal sürüntü örneklerinde 2009 yılı ile 2010 yılında sırasıyla \%7.8 ve \%12.7 oranlarında C.psittaci pozitifliği belirlenmiştir. Aynı çalışmada dışkı örneklerinden havuz oluşturarak çalışıldığında 2009 yılında \%46.7, 2010 yılında da \%76.7 oranında pozitiflik saptanmıştır. Araştırmacılar iki yıl arasındaki bu artışı açıklayamadıklarını, ancak bu durumun sürüye yeni yabani kuşların katılması, stres faktörleri, klamidyanın dışkı ile yayılması sonucu ya da eş zamanlı 
bir enfeksiyonun varlığından kaynaklanabileceğini belirtmişlerdir ${ }^{18}$. Hollanda'da yapılan bir çalışmada yine yabani güvercinlerde PCR ile iki farklı şehirde güvercin dışkı örnekleri toplanmış ve Utrecht şehrinde \%2.4, Haarlem şehrinde ise \%7.5 oranında C.psittaci belirlenmiştir ${ }^{11}$. Stenzel ve arkadaşlarının Polonya' da evcil ve yabani güvercinlerde C.psittaci prevalansını araştırdıkları çalışmada ${ }^{19}$ ortalama prevalans \%6.8 olarak belirlenmiş ve prevalansın yabani güvercinlerde daha yüksek oranda olduğu tespit edilmiştir. Kore'de ise yabani güvercinlerde C.psittaci prevalansı \%1.8 oranında belirlenmiştir ${ }^{8}$. Bu çalışmada evcil güvercin dışkı örneklerinde C.psittaci \%6 olarak belirlenmiştir. Elde edilen bu bulgu yukarıda belirtilen araştırmalarla uyumludur. Ülkemizde ise hastalığın kanatlı hayvanlarda görülme sıklığı üzerine çok az sayıda çalışma yapılmıştır. Çelebi ve arkadaşları tarafından yabani güvercinlerden alınan örneklerde (sürüntü) PCR yöntemiyle gerçekleştirilen çalışmada $^{20} \% 34.4$ oranında C.psittaci (ompA geni) belirlenmiştir. Sareyyüpoğlu ve arkadaşları tarafından kafes kuşlarında yapılan çalışmada ${ }^{21}$ dışkıdan alınan sürüntü örneklerinin \%91.5'inde PCR yöntemi (ompA geni) ile etkenin DNA'sının saptandığı bildirilmiştir. Yabani güvercinlerle yapılan çalışmalara göre sunulan bu araştırmada C.psittaci'nin daha düşük oranda izole edilmesinin nedeni bu çalışmadaki güvercinlerin evcil olmaları, aile işletmesi tarzında kapalı ortamlarda daha hijyenik koşullarda bakılmaları ve yabani hayvanlarla karşılaşıp etkenin bulaşmasının kısıtlı olmasıyla açıklanabilir. Yine örneklerin alındığı hayvanların yetiştirilme, barınak, ırk, bölge ve yıl farkından da kaynaklanabileceği düşünülmektedir. Ayrıca, bu çalışmada pozitif çıkan örneklerin üçünün kış dönemi, üçünün de yaz dönemi alınan örneklerden ve aynı işletmelerden olması; etkenin aynı kümeste uzun süre dışkı ile saçılabildiğini göstermektedir. Ki-kare testine göre bu çalışmada mevsimin etkisi yoktur. Ancak Hollanda'da yapılan bir çalışmada, Amsterdam'da yaşayan yabani güvercinlerden Mayıs ayında toplanan örneklerde (\%10) Şubat ayında toplanan dışkı örneklerine (\%5) göre daha yüksek oranda C.psittaci belirlenmiştir. Bu durum, Mayıs ayının çiftleşme ayı olmasına ve stres faktörünün artmasına bağlı olarak güvercin dışkılarında etkenin atılımındaki artışa bağlanmıştır ${ }^{22}$.

C.psittaci etkeninin hücre duvarı dış zarında bulunan proteinlere göre kanatlılarda altı (A-F), memelilerde iki (WC ve M56) serotip/genotip belirlenmiştir. Ayrıca yaygın olmayan 1V, YP84, R54, 6N, CPX0308, I gibi alt genotipler de bildirilmiştir. Serotiplerde konak özgüllüğü bulunmaktadır. Güvencinlerde tüm dünyada yaygın olarak belirlenen serotip B dir ${ }^{8,11}$. Ingiltere'de güvercin haricindeki yabani kuşlarda yapılan bir çalışmada belirlenen C.psittaci etkenlerinin tümünün A genotipinde olduğu ortaya konmuştur ${ }^{16}$. Burt ve arkadaşları ${ }^{11}$ güvercinlerden izole edilen tüm klamidya izolatlarının genotip B olduğunu bildirmişlerdir. Stenzel ve arkadaşları ${ }^{19}$ güvercin kökenli izolatların \%88.2'sini genotip B, kalan izolatları da genotip E olarak belirlemişlerdir. Literatürde farklı olarak Sachse ve arkadaşlarının Almanya'da yaptıkları çalışmada ${ }^{18}$ güvercinlerde C.psittaci'nin en yaygın genotipi B olarak belirlense de izolatların \%13.4'ünün farklı genotipte olduğu tespit edilmiştir. Genotip A'da altı izolat ve daha egzotik olan CPX0308 alt genotipini ise bir izolatta belirlemişlerdir. Yapılan bu çalışmada da NCBI (National Center for Biotechnology Information) Dünya veri bankasında mevcut dizi analizleriyle karşılaştırıldığında 
izolat genotiplerinin \%100 genotip B, \%99 genotip E ile uyum gösterdiği ortaya çıkmıştır. Türkiye'de ilk defa C.psittaci izolatlarında genotip belirlenmiş olup, daha önce diğer ülkelerde yapılan çalışmalarla benzer sonuçlar bulunmuştur.

Sonuç olarak, bu çalışmada Ankara ve ilçelerinde evcil güvercin dışkı örneklerinde \%6 oranında C.psittaci ompA geninin varlığı belirlenmiştir. Bu genin dizi analizi ile de \%100 genotip B, \%99 genotip E ile uyumluluk gösterdiği ortaya konmuştur. Ayrıca yaz ve kış mevsimleri arasında farklılık önemsiz bulunmuştur. Türkiye'de ilk defa evcil güvercin dışkı kökenli C.psittaci genotipi bu çalışma ile belirlenmiştir. Kanatlı hayvanlarda önemli hastalıklardan biri olan klamidiyozis etkeninin zoonotik olması ve evcil güvercinlerde düşük oranda bile bulunması halk sağlığı açısından önemlidir.

\section{ÇIKAR ÇATIŞMASI}

Yazarlar bu makale ile ilgili herhangi bir çıkar çatışması bildirmemişlerdir.

\section{KAYNAKLAR}

1. Dickx V, Beeckmen DSA, Dossche L, Tavernier P, VanrompAy D. Chlamydophila psittaci in homing and feral pigeons and zoonotic transmission. J Med Microbiol 2010;59(Pt11):1348-53.

2. Baş B, Dinç G. Kuşlarda ve insanlarda Chlamydophila psittaci enfeksiyonu. Turk Hij Den Biyol Derg 2015;72(1):73-8.

3. Agunos A, Pierson FW, Lungu B, Dunn PA, Tablante N. Review of nonfoodborne zoonotic and potentially zoonotic poultry diseases. Avian Dis 2016;60(3):553-75.

4. Guo W, Li J, Kaltenboeck B, Gong J, Fan W, Wang C. Chlamydia gallinacea, not C.psittaci, is the endemic chlamydial species in chicken (Gallus gallus). Sci Rep 2016;6:19638.

5. Wannaratana S, Thontiravong A, Amonsin A, Pakpinyo S. Persistence of Chlamydia psittaci in various temperatures and times. Avian Dis 2017;61(1):40-5.

6. West A. A brief review of Chlamydophila psittaci in birds and humans. J Exot Pet Med 2011;20(1):18-20.

7. OIE (2018). Avian chlamydiosis. Erişim Adresi: http://www.oie.int/fileadmin/Home/eng/Health_standards/ tahm/2.03.01_AVIAN_CHLAMYD.pdf (Erişim Tarihi: 06.04.2018).

8. Jeong J, An I, Oem J, Wang S, Kim Y, Shin J, et al. Molecular prevalence and genotyping of Chlamydia spp. in wild birds from South Korea. J Vet Med Sci 2017;79(7):1204-9.

9. Cheong HC, Lee CYQ, Cheok YY, Yi Tan GM, Looi CY, Wong WF. Chlamydiaceae: diseases in primary hosts and zoonosis microorganisms. Microorganisms 2019;7(5):E146.

10. VanrompAy D. Avian chlamydiosis, pp: 1055-73. In: Swayne DE, Glisson JR, McDougald LR, Nolan LK, Suarez DL, Nair V (eds), Diseases of Poultry. 2013,13th ed. Pondicherry, India.

11. Burt SA, Röring RE, Heijne M. Chlamydia psittaci and C.avium in feral pigeon (Columba livia domestica) droppings in two cities in the Netherlands. Vet Q 2018;38(1):63-6.

12. Sambrook J, Russell DW. Molecular cloning: a laboratory manual, pp: 461-471. In: Sambrook J (ed). Molecular Cloning: A Laboratory Manual. 2002, $3^{\text {rd }}$ ed. Science Press, Beijing.

13. Laroucau K, Trichereau A, Vorimore F, Mahe AM. A pmp genes-based PCR as a valuable tool for the diagnosis of avian chlamydiosis. Vet Microbiol 2007;121(1-2):150-7.

14. Laroucau K, Souriau A, Rodolakis A. Improved sensitivity of PCR for Chlamydophila using omp genes. Vet Microbiol 2001;82(2):155-64.

15. Krawiec M, Piasecki T, Wieliczko A. Prevalence of Chlamydia psittaci and other Chlamydia species in wild birds in Poland. J Vector Borne Dis 2015;15(11):652-5. 
16. Beckmann KM, Borel N, Pocknell AM, Dagleish M P, Sachse K, John SK, et al. Chlamydiosis in British Garden Birds (2005-2011): retrospective diagnosis and Chlamydia psittaci genotype determination. Eco Health 2014;11(4):544-63.

17. Magnino S, Haag Wackernagel D, Geigenfeind I, Helmecke S, Dovc A, Prukner Radovcic E, et al. Chlamydial infections in feral pigeons in Europe: review of data and focus on public health implications. Vet Microbiol 2009;135(1-2):54-67.

18. Sachse K, Kuehlewind S, Ruettger A, Schubert E, Rohde G. More than classical Chlamydia psittaci in urban pigeons. Vet Mic 2012;157(3-4):476-80.

19. Stenzel T, Pestka D, Choszcz D. The prevalence and genetic characterization of Chlamydia psittaci from domestic and feral pigeons in Poland and the correlation between infection rate and incidence of pigeon circovirus. Poult Sci 2014;93(12):3009-16.

20. Çelebi B, Ak S. A compArative study of detecting Chlamydophila psittaci in pet birds using isolation in embryonated egg and polymerase chain reaction. Avian Dis 2006;50(4):483-9.

21. Sareyyüpoğlu B, Cantekin Z, Bas B. Chlamydophila psittaci DNA detection in the faeces of cage birds. Zoonozes Public Health 2007;54(6-7):237-42.

22. Heddema ER, Ter Sluis S, Buys JA, Vandenbroucke-Grauls CM, van Wijnen JH, Visser CE. Prevalence of Chlamydophila psittaci in fecal droppings from feral pigeons in Amsterdam, The Netherlands. Appl Environ Microbiol 2006;72(6):4423-5. 